\title{
Extracurricular Organizations that Grow the Potential Leadership of Vocational School Students in Indonesia
}

\author{
Khaidir Rahman Nasir ${ }^{1,2, *}$, Marji ${ }^{1}$, Syamsul Hadi ${ }^{1}$, Hary Suswanto ${ }^{1}$, Didik Nurhadi $^{1}$ \\ ${ }^{1}$ Faculty of Engineering, State University of Malang, Malang City, 65111, Jawa Timur, Indonesia \\ ${ }^{2}$ Teknik Informatika, STMIK AKBA, Makassar City, 90234, Sulawesi Selatan, Indonesia
}

Received July 17, 2020; Revised November 7, 2020; Accepted November 29, 2020

\section{Cite This Paper in the following Citation Styles}

(a): [1] Khaidir Rahman Nasir, Marji, Syamsul Hadi, Hary Suswanto, Didik Nurhadi , "Extracurricular Organizations that Grow the Potential Leadership of Vocational School Students in Indonesia," Universal Journal of Educational Research, Vol. 8, No. 12A, pp. 7258 - 7267, 2020. DOI: 10.13189/ujer.2020.082508.

(b): Khaidir Rahman Nasir, Marji, Syamsul Hadi, Hary Suswanto, Didik Nurhadi (2020). Extracurricular Organizations that Grow the Potential Leadership of Vocational School Students in Indonesia. Universal Journal of Educational Research, 8(12A), 7258 - 7267. DOI: 10.13189/ujer.2020.082508.

Copyright $\subseteq 2020$ by authors, all rights reserved. Authors agree that this article remains permanently open access under the terms of the Creative Commons Attribution License 4.0 International License

\begin{abstract}
Extracurricular activities are an organization that fosters student leadership potential and cannot be separated from the roles of other people in everyday life, without people who are willing to work together and encourage them to become leaders. All abilities, skills, potentials, and talents that exist within each student will not be able to appear and develop optimally. For students and coaches who have not been able to foster leadership attitudes in students so that teachers need to act as facilitators in all things that can foster student leadership attitudes in schools. The purpose of this study was to determine teacher leadership to develop student leadership potential through the activities of vocational school student organizations in Indonesia. This type of research is a multi-site study with a qualitative approach. The number of informants was 30 people consisting of extracurricular guidance teachers, heads of extracurricular organizations, and deputy principals of student affairs at State Vocational Schools in Tulungagung Regency, East Java Province. Data collection techniques are observation and in-depth interviews using questions that have been compiled. The data obtained will be analyzed using content and subject triangulation. The findings of this study indicate that teacher leadership that is implemented in extracurricular activities to foster student leadership potential is an independent, creative, communicative attitude, social spirit, cooperation, and decision making and honesty on the responsibilities so that they become perfect leaders.
\end{abstract}

Keywords Extraluricular Organizations, Student Leadership, SMK

\section{Introduction}

The progress of an organization depends on the leader's ability to control personal, utility, resources, and other resources [4]. The problem of leadership is an urgent problem faced by the Indonesian people, especially in East Java. This certainly makes the community increasingly distrust leaders and assumes all leaders have dishonest attitudes. In line with [22], leadership greatly determines the success of management, and more than that it determines the success of administration, this means that it will determine the achievement of goals and according to the statement of Research [18] shows that leadership style plays an important role in personality traits in the education system.

When the researcher observed one of the Vocational High Schools in the Tulungagung district, there was a problem, namely that some students who were members of certain school organizations did not have an attitude of politeness and respect for their elders. When submitting an activity proposal and it was not immediately approved by the school, these students remained adamant about the contents of the proposal, even tending to impose their opinion. Some students made extracurricular activities as 
an excuse for not participating in classroom learning activities, even though there was no official interest or dispensation. leadership is the influence that is deliberately exercised by one person on another to structure (organize) activities and relationships within a group or organization[15], One of the roles of the teacher in a class is as a leader [13], in the learning process it is expected that the teacher and students interact well to create a conducive atmosphere to motivate students to participate in the learning process [2] and the power that comes from it. The teacher can also have respect and a relationship because it has a noble position, so it deserves to be digested and emulated [34].

The student organization will progress and develop if it is led by people who are truly capable of leading a particular organization. This statement is supported by a statement [1] a leader does not only influence subordinates but as a central point that determines the direction of the organization's journey about to with concerning the various possible changes that occur in the organizational environment. Opinion [44] namely leadership is an attempt to direct and influence others to achieve certain goals.

One of the districts located in East Java Province, Indonesia. The government center of the Tulungagung Regency is in Tulungagung District. Tulungagung is well-known as one of the few educational cities in Indonesia and is located $154 \mathrm{~km}$ southwest of Surabaya City, the capital of East Java Province. SMKN 1 Boyolangu and SMK 1 Rejotangan which are located in Tulungagung Regency is one of the schools that hold extracurricular activities. By participating in this activity students are expected to be able to develop the potential of students to become successful human beings and have noble character. Organizational activities teach students leadership attitudes, so that they will become individuals who are tough, honest, responsible, and carry out the mandate.

This is by following and under the opinion [12] which states that a leader is a person who has responsibility in the process of improving educational institutions. All abilities, skills, potentials, and talents that exist within each individual will not be able to emerge and develop optimally [3], and [32] suggest that leadership development is an integral part of student education programs, with courses and activities that run the entirety of curricular classes offered by a variety of academic disciplines (such as business, psychology, political science, history, military science, and education) to co-curricular programs offered by various student affairs offices (from admissions and athletics to student government, and community service centers). by creating a strong education that involves action, reflection, cognition, and experience, students can be better equipped to lead in a world with complex moral problems and the demands of competition for sources of time, energy, and organization [19], Educating students in transformational leadership will enable leaders to increase awareness of themselves, their followers and ultimately the organization, embracing trust and emphasizing the interplay of relationships [17]. According to [38] there is a relationship between leadership positions and the role of students as agents of social change, a link that has the potential to influence their civic and social change involvement in educational institutions and beyond. Furthermore, the research presentation [8] also discusses student leadership development. Educating students in transformational leadership will enable student leaders to increase awareness of themselves, their followers, and ultimately the organization, embrace trust, and emphasize the interplay of relationships [17]. According to [38] there is a relationship between leadership positions and the role of students as agents of social change, a link that has the potential to influence their civic and social change involvement in educational institutions and beyond. Furthermore, the research presentation [8] also discusses student leadership development. Educating students in transformational leadership will enable student leaders to increase awareness of themselves, their followers, and ultimately the organization, embrace trust, and emphasize the interplay of relationships [17]. According to [38] there is a relationship between leadership positions and the role of students as agents of social change, a link that has the potential to influence their civic and social change involvement in educational institutions and beyond. Furthermore, the research presentation [8] also discusses student leadership development. According to [38] there is a relationship between leadership positions and the role of students as agents of social change, a link that has the potential to influence their civic and social change involvement in educational institutions and beyond. Furthermore, the research presentation [8] also discusses student leadership development. According to [38] there is a relationship between leadership positions and the role of students as agents of social change, a link that has the potential to influence their civic and social change involvement in educational institutions and beyond. Furthermore, the research presentation [8] also discusses student leadership development.

Taking on leadership roles in classrooms, associations, clubs, and others will prepare students for the many challenges they may face after their university life [30]. According to [33] student leadership can be an effective tool in dealing with environmental problems and promoting environmental education. The leader is not only someone who is first among equals but also has a voice to comfort others while the work is being carried out [20]. The role of a mentor teacher is very important in developing student leadership potential through extracurricular activities. This is consistent with a study [16] that found that young men and women who perceive their adult support as more positive have a more positive 
perception of their leadership skills.

These findings contribute to future school and community-based prevention and intervention programs, demonstrating the importance of youth leadership involvement at all grade levels and the influence of adult support on youth perceptions of their leadership skills. One part of social skills is social behavior, this social behavior becomes very important 999///in the midst of various social problems that often occur in the social environment.[42]. Based on the phenomena described, the researcher urges to examine how teacher leadership develops student leadership in extracurricular activities for students at SMKN 1 Boyolangu, and SMKN 1 Rejotangan, Tulungagung district.

\section{Method}

\subsection{Research Model}

This type of research is a multi-site case study. The approach used in this study is qualitative. A problem in qualitative research indicates the need to be studied, describes a problem or problem that must be studied, and researched, and places a wider scope of education as well as a social context. The statement of the problem is a summary of the entire literature which constitutes the substance of the study, with several more detailed references [6]. This study seeks to reveal and describe various conditions or phenomena of the reality of teacher leadership in developing student leadership potential through extracurricular activities for vocational students. With this, researchers can understand and give meaning to a series of descriptions of the reality of teacher leadership in the school.

\subsection{Participants}

In this study, the sampling method used in determining participants in the qualitative section. The researchers chose SMK schools in East Java for several reasons. First, the choice of location is because Tulungagung Regency plays an important role in the development process, especially as a means of developing leadership education in terms of creating technology skills transfer and transforming scientific approaches to create technology skills transfer and compete in the global era. Second, the school runs extracurricular activities in the spirit of the leadership of the coaching teacher to the students. Third, school rules are very open to organizations that will carry out activities outside of school. Fourth, chose two scout organizations and PMR because it is a large organization recognized by the state and every activity in this organization plays an important role in developing a leadership spirit and communicating with every student. The total sample size is 30 people, consisting of supervisor teachers, vice-principals, heads of organizations, and members of the organization (students).

\subsection{Data Collection}

The data collection techniques used were interviews and documentation. An interview is a conversation with a specific purpose. The conversation was carried out by two parties, namely the interviewer (interviewer) who asked the question, and the interviewer (interviewer) who answered the question. The informants who will be interviewed are the guidance teacher, students (head of the organization), and the student field vice principal. In this interview, researchers obtained data about teacher leadership in developing student leadership potential in organizations. Meanwhile, documentation is one of the qualitative data collection methods by viewing or analyzing documents made by the subject himself or by others regarding the subject, and the data obtained is analyzed using content and subject triangulation.

At the first meeting the researchers interviewed in-depth with the subject regarding the background of teacher leadership, problems regarding student leadership attitudes, how the daily behavior of students in leading organizations in the school, since when did the problem arise, and whether the subject was aware of a problem, and what efforts had been made to overcome these problems. The second meeting discussed what tips are carried out by the teacher to develop the potential for student leadership, whether it is the recruitment of new members, the election and inauguration of organizational administrators, the preparation of organizational activity programs; and any program of activities that can develop student leadership potential. The third meeting discussed how the implementation of student organization activities, both routine and incidental activities, how teacher leadership is in fostering student members of the organization, and how the role of organizational members in the preparation of work programs and the implementation of organizational activities. In The fourth meeting, researchers interviewed the field of student affairs, aimed to explore data about the impact of student organization activities on school progress, management of student organizational activities, and allocation of funds, and the flow of fund submissions for the implementation of student organization activity programs. Documentation studies are carried out to find out data about the student's organizational structure, a program of activities, schedule for the implementation of activities, as well as the attendance list of organizational members in routine activities (in this case, self-development training activities). and what is the role of organizational members in the preparation of work programs and the implementation of organizational activities?. In The fourth meeting, researchers interviewed the field of student affairs, aimed to explore data about the impact of student 
organization activities on school progress, management of student organizational activities, and allocation of funds, and the flow of fund submissions for the implementation of student organization activity programs. Documentation studies are carried out to find out data about the student's organizational structure, a program of activities, schedule for the implementation of activities, as well as the attendance list of organizational members in routine activities (in this case, self-development training activities). and what is the role of organizational members in the preparation of work programs and the implementation of organizational activities?. In The fourth meeting, researchers interviewed the field of student affairs, aimed to explore data about the impact of student organization activities on school progress, management of student organizational activities, and allocation of funds, and the flow of fund submissions for the implementation of student organization activity programs. Documentation studies are carried out to find out data about the student's organizational structure, a program of activities, schedule for the implementation of activities, as well as the attendance list of organizational members in routine activities (in this case, self-development training activities). management of student organizational activities, and allocation of funds, and fund submission flow for the implementation of student organization activity programs. Documentation studies are carried out to find out data about the student's organizational structure, the program of activities, schedule for the implementation of activities, as well as the attendance list of organizational members in routine activities (in this case, self-development training activities). management of student organizational activities, and allocation of funds, and fund submission flow for the implementation of student organization activity programs. Documentation studies are carried out to find out data about the student's organizational structure, a program of activities, schedule for the implementation of activities, as well as the attendance list of organizational members in routine activities (in this case, self-development training activities).

Researchers chose guidance teachers as informants because they are implementers and facilitators in activities that exist in student organizations. The supervisor (along with the organization's daily committee) is also the compiler of the work program design and activities to be carried out by the student organization in a certain period, namely in one academic year. Therefore, the guidance teacher is expected to be able to provide information to researchers about the efforts made by the guidance teacher to develop student leadership potential. Students become informants in this study because they carry out student organizational activities that have been designed together with the teacher and approved by the school management team.

\section{Findings and Interpretation}

\subsection{Findings in Scout Organizations}

Regarding student leadership attitudes and how students everyday behavior in leading extracurricular activities, it is very good seen from the explanation that learning carried out in educational institutions, especially at SMK is not only carried out in the classroom but also carried out outside the classroom, namely through extracurricular activities. Extracurricular is an activity carried out outside of class hours that has an organizational structure and extracurricular coaches. The Scout Organization at SMKN 1 Boyolangu Tulungagung, Scout extracurricular activities are fostered by internal coaches (teachers) and external coaches (coming from outside the school). and field results when conducting activities at school, but in the implementation of the problems that often arise during the coordination system between members and coaches, there are often problems during training or administration. This is consistent in the case of research. Teacher leadership in learning can come from coercive power, legitimacy, expertise, appreciation, relevance, information, or relationships. (Informant 1: Deputy Principal of Student Affairs).

The theory that supports it, the teacher has the power to force because it is seen from the age and maturity, which is relatively older than the students. So that teachers have more authority because they have the legitimacy of the school to teach and have the expertise and information that these students need. A Power that comes from respect and relationships can also be possessed by a teacher because he has a noble position so that he should be dignified and emulated.[34]. Efforts from the school to overcome this problem by holding and participating in basic leadership training activities for students and coaches, which are included in training activities carried out both internally and the local government to foster attitudes and leadership that can be applied in extracurricular organizations that are in school. So that the results of these activities, that the supervisor teacher has been able to provide leadership qualities to students which can be seen in developing student leadership potential in the form of selecting external coaches, activities that motivate students and make them active in every activity that is included, as well as understanding centered on students. Create leadership opportunities for each student individually and provide broader thinking skills about leadership. Teachers also provide opportunities for students to express themselves better so that students can develop different perspectives to better recognize themselves and their surroundings [27].

Implementation of student organization activities at SMKN 1 Boyolangu, extracurricular activities are routinely carried out every week, namely every Wednesday after class hours are over. However, if there 
are Scouting activities that carry the name of the school such as Jamboree activities, Level Competitions (LT), Community Service Camp, Galang Rally, and so on, then the extracurricular member students who are on duty will be given dispensation to focus on Scouting activities. The role of the teacher as a facilitator, in this case, is to apply for a dispensation to the teaching teacher in the class to permit student Scout members. This is because the activities carried out aim to bring the good name of the school to the community. Every training activity regularly, the teacher always assists student members of the organization. Even though there are external trainers who are truly experts in the field of scouting skills, the teacher feels it is still necessary to assists so that the figure of responsibility is always held, this is a form of responsibility so that students can imitate these benefits. As the supervisor, always convey to scout students who take part in every activity outside the classroom, that students will gain experience and leadership qualities that are useful for carrying out various social activities including in terms of building good personal character, responsibility for the school, and family environment, and create social awareness in students. So that the scouting activities put forward by students have become at the forefront. In other words, students are more aware of the environment where teachers are free to express themselves, and making students active in the decision-making process at school and the classroom is considered important. (Informant 2: Coaching Teacher).

One of the activities carried out by the Boyolangu Boyolangu Scout extracurricular activity was the Galang Rally activity. Galang Rally is a collection of competitions with participants consisting of SMP / MTs students. The organizing committee for the competition was the Boyolangu 1 Vocational High School Scouts, in the Galang Rally activity consisting of several types of competitions, namely Photography, Pioneering, Logo Design, Pensi, LBB, Yell-Yel, Outbound, and Bivouac competitions. The entire series of activities are carried out by student Scout members, starting from planning events, drafting proposals, submitting proposals to the management team, procurement of needs, competition equipment, publications, documentation, briefings, technical meetings, running competitions, assessing and judging, and so on. Activities like this are one of the efforts carried out by extracurricular coaches to develop the potential for leadership and student responsibility. All of these competition activities are given entirely by Scout members. The results of the competition certainly have a positive impact, both for competition participants (SMP and MTs students), for Scout members, and for schools, namely as a means of promotion to foster public interest in choosing SMKN 1 Boyolangu as further education after graduating from SMP / MTs. . So that when students finish the organizational stewardship period at school, students can be more skilled and more proficient in solving the problems they face, both personal and group problems. This is in line with the results of [29] that knowing skills and communication in leading and developing a more effective model results in good leadership. Osteen, Owen, Komives, Mainella, and Longerbeam [27] say that leadership is the identity of the person who creates his leadership in the process. In this case, students at the time of making decisions can be faster and more precise and proficient in communicating. So that each student individually will have broader leadership qualities and thinking skills. Students will also express themselves better and be able to improve themselves so that they can be sensitive to the surrounding environment. (Informant 3: head of a student organization).

The Galang Rally activity that involves the outside community is an idea that was initiated by teachers and external coaches to develop the ability of student members of the organization to become leaders. This is because the Galang Rally activity can train students to deal directly with the community outside the school, coordinate with various related parties, design and arrange program implementation and budget funds, and so on. These things can develop the leadership potential that is in students. Another thing that teachers and external coaches do is to direct and provide some suggestions regarding the implementation of the competition.

The Scout extracurricular activities at SMKN 1 Rejotangan also have internal and external trainers. Internal trainers are teachers of SMKN 1 Rejotangan, while external coaches are Scout coaches from outside educational institutions. Scout extracurricular activities are carried out once a week on Sundays. Unlike the Scout extracurricular at SMKN 1 Boyolangu which carries out Scouting activities on effective days, SMKN 1 Rejotangan carries out organizational activities on Sundays because the school carries out formal learning activities (in class) into 2 shifts, namely the morning shift (07.00-11.30) and day shift (12.00-17.30). This is due to the lack of classrooms, so learning activities are divided into 2 shifts. Nevertheless, extracurricular activities are still carried out optimally regardless of the circumstances. At SMKN 1 Rejotangan, the teacher's role is as a facilitator where the teacher also assists student members of the organization in organizational activities.

However, SMKN 1 Rejotangan has never held an event involving the community outside the school. This is because the procurement of activities related to the outside community requires a fairly long process. Also, the guidance teacher feels that the routine activities carried out in schools are good and effective enough for the development of student skills. It can be seen that students who have participated in scouting organizations for one year can produce a leadership spirit both in the classroom during the PBM process and during activities outside the class, all scout students become an example for other 
students. because in the Boy Scout organization we are taught independence in leading and character building so that we can become a role model for everyone. (Informant 4: students)

At SMKN 1 Boyolangu and SMKN 1 Rejotangan, the preparation of organizational activity programs is jointly carried out by teachers and student members of the organization, starting from the recruitment of new members, the preparation and inauguration of organizational management, and the preparation of organizational work programs carried out by supervisor teachers and student members of the organization through deliberation meeting. This implementation encourages students to always be democratic, responsible, and honest in all matters which of course is one of the leadership attitudes. In the explanation above we conclude that responsibility is involved is a very important quality of student leadership. So that can be said that students are more able to control their behavior, fulfilling assigned tasks, and acting with this awareness is the basis of responsibility. The students are more aware of the responsibilities assigned to the school organization and their daily life. Students need to acquire leadership qualities. Plus in terms of honesty is one of the important leadership qualities for students that must be possessed. The individual behavior of students is based on certain values and strengths of character which are very important for honesty $[5,11,29]$

\subsection{Findings in Youth Red Cross (PMR) Extracurricular Activities}

The explanation of the extracurricular organization PMR (Youth Red Cross) is part of the PMI (Indonesian Red Cross) which is specifically implemented in educational institutions (schools). One of the privileges of students who take part in PMR is that PMR members who are on duty as a health team is not allowed to join the march in the flag ceremony, PMS members usually prepare in the backyard which is usually shady while watching in case some students are tired, sick, or fall unconscious or prepare in the UKS room waiting for students who need further treatment. (Informant 5: coach teacher), Extracurricular PMR (Youth Red Cross) is a student actively engaged in the social and health sectors. PMR is one of the extracurricular activities in schools that are very useful for teenagers to participate in. Following the name and the organization that supervises it, PMR focuses more on teaching students about health and medicine. Usually, PMR becomes an extracurricular activity that is of interest to students who aspire to become doctors, midwives, nurses, or those related to health and medicine. PMR is relatively less in demand when compared to extracurricular activities such as Scouts or intra-organization (OSIS). (Informant 6: head of the organization).
They think that extracurricular activities are less prestigious for gaining popularity in school. Activities in PMR are not only limited to the fields of health and medicine, but many activities are very useful and can be applied in everyday life. (info man 7: students). Student leadership is something that must be developed because in the future they will become leaders and future generations of the nation. An educational institution even has an effort that is specifically aimed at developing student leadership potential, one of which is the Student Leadership Development Series Program. Students enjoy interacting with other leaders in the pharmacy program and learning more about themselves, which allows them to differentiate themselves as leaders. This leadership program is designed to provide some opportunities for students to self-identify their leadership style, discuss obstacles often faced by leaders, understand how to build relationships that are important to leaders, help them to become mentors to other students, and put knowledge and their leadership skills in practice. Reflecting on these activities and assessment of objectives, the strength of the program appears to lie in students identifying their leadership style, building relationships, solving problems, overcoming barriers, and having the opportunity to put leadership knowledge and skills into practice. discuss barriers often faced by leaders, understand how to build relationships that are important to leaders, help them to mentor other students, and put their leadership knowledge and skills into practice. Reflecting on these activities and assessment of objectives, the strength of the program appears to lie in students identifying their leadership style, building relationships, solving problems, overcoming barriers, and having the opportunity to put leadership knowledge and skills into practice. discuss barriers often faced by leaders, understand how to build relationships that are important to leaders, help them to mentor other students, and put their leadership knowledge and skills into practice. Reflecting on these activities and assessment of objectives, the strength of the program appears to lie in students identifying their leadership style, building relationships, solving problems, overcoming barriers, and having the opportunity to put leadership knowledge and skills into practice.[7,39].

At SMKN 1 Boyolangu there is a PMR extracurricular activity. PMR coaches consist of internal coaches, namely school teachers, and external coaches, namely members of the PMI Tulungagung Regency. At SMKN 1 Boyolangu, extracurricular internal coaches tend to be fixed and reshuffle is rarely held if there is no problem or requests from extracurricular member students. PMR extracurricular always carries out routine activities every week. PMR extracurricular activities at SMKN 1 Boyolangu are held on Wednesdays and Saturdays. Routine activities usually discuss matters related to health such as medication, first aid, and self-development activities such as Line Training (LBB), Outbound, 
evacuation, and disaster management, public kitchens, and others. It is intended that PMR students have a capable and responsive attitude in dealing with all problems. Self-development activities are not only carried out on the PMR activity schedule, but are also carried out when there are events held by schools such as flag ceremony activities, Student Orientation Period (MOS), Future Group Orientation Period (MOGD), and so on. During the flag ceremony on Monday, PMR members were always on standby to provide first aid to students who were sick or fainted. Students on duty are scheduled on a rotating basis. Also, there are PMR students who work in the School Health Unit (UKS) together with UKS officers to assist students who need medical assistance while in the school environment. (Informant 8: coach teacher).

The events held by PMR which are routinely held at certain periods are training and blood donation held by PMI Tulungagung Regency for residents of SMKN 1 Boyolangu. The blood donation activity executive officer is a PMR member who is supervised by a member of the PMI Tulungagung Regency. Other activities that have been carried out by PMR SMKN 1 Boyolangu are training in disaster management and evacuation. These activities are an effort to develop a student's potential, especially in terms of leadership and the ability to organize and coordinate well. Students in organizations with leadership qualities know what they want [44, 29]. Increasing the ability to organize with the aim of students at an early age can make it easier for them to plan for the future in various fields and increase their effectiveness in their careers. (informant 9: head of the organization).

PMR extracurricular at SMKN 1 Rejotangan also carry out routine activities that are held every Sunday. As with SMKN 1 Boyolangu, PMR members at SMKN 1 Rejotangan are in charge of health and medicine at the school. At SMKN 1 Rejotangan, PMR coaches come from external and internal coaches. External coaches come from outside the school institution, namely members of the PMI Tulungagung Regency. Meanwhile, the internal coaches are teachers of SMKN 1 Rejotangan, namely productive teachers of the Nursing Skills Program (KPR). It should be noted that SMKN 1 Rejotangan has a Nursing expertise program so that PMR extracurricular activities are truly guided by teachers with a nursing background. Even PMR members and students of the KPR expertise program always oversee the NU Banser Training activities. This activity supports the development of leadership potential because students interact directly with the community. At SMKN 1 Rejotangan, the internal supervisor is always reshuffled at each period. This is different from SMKN 1 Boyolangu which is always constant and does not replace the internal coach if there are no problems or requests from extracurricular member students. It appears that the implementation of the proposed activities at school is important because students who spend most of their time in school are expected to focus more on leadership in organizations and the multidimensional development process. It is important to present people who have come forward with their leadership qualities in history, undertaking studies of living leaders, and conducting activities for a conceptual understanding of leadership. Several studies are supporting this result [10, 14, 42]. (informant 10: students).

Extracurricular PMR SMKN 1 Rejotangan carries out activities that are more or less the same as PMR SMKN 1 Boyolangu, namely as a team that is ready to handle health, medication, and first aid for activities carried out by schools both routine and incidental activities such as the flag ceremony on Monday, events held by other extracurricular activities, for example, Education and Training, MOS, MOGD, and so on. This aims to develop the leadership potential of PMR member students following their main duties and functions, namely dealing with health and medical problems in educational institutions (schools) and the community. (informant 11: coach teacher).

Based on this discussion, the mentor teacher seeks to develop student leadership potential through student organizational activities. Student organization activities aim to develop student potential, this is following the research [21] which states that extracurricular activities are a vehicle for developing talents and interests of students, wherein extracurricular activities students can choose their specialization according to their abilities and talents. The role of a mentor teacher is very important in developing student leadership potential through extracurricular activities. The results of [16] stated that young men and women who perceive their adult support as more positive have a more positive perception of their leadership skills. The teacher's role in developing student leadership potential is as a facilitator who facilitates students in their organizational activities with the aim of their leadership potential being able to develop and provide benefits to others today and in the future.

Education in schools consists of extracurricular education, namely educational and teaching programs consisting of various subjects that are following the content of the educational and extracurricular curriculum which functions to optimally foster and develop the talents and interests of students.[37]. Extracurricular education is an activity that is carried out outside of class hours which aims to develop the interests and talents of students [41]. Through this extracurricular activity, the development and development of talents and interests of students as part of the younger generation are pursued and realized in schools. Extracurricular activities are fields for self-actualization which are sometimes not found in daily teaching and learning activities, both in leadership, sports, arts, and religion. Extracurricular development can be beneficial for schools, namely as a means of school promotion to the community, especially the community around the school [37]. 


\section{Conclusions}

Extracurricular activities nationally at Vocational High Schools in Indonesia as well as in the Province of East Java and the District of Tulungagung specifically that seek to develop leadership potential, namely in the form of independent, creative, character, and communicative attitudes It can be seen that effective communication skills $[37,38,40]$, Scout extracurricular coaches, both internal and external coaches work together to facilitate student Scout members to interact with the community outside of schools which aims to develop student leadership potential during society. Meanwhile, Scout's extracurricular coaches prioritize general skills that must be mastered by Scout members. Scout coaches consist of mentors and external coaches (Kwarda Kabupaten Tulungagung), in line with this study $[36,39,41]$. To be able to communicate well verbally or in writing, trying to understand and listen to others carefully, and to be able to make decisions together are among the important leadership qualities [35]. Student communication skills may not be sufficiently developed because of the emergence of loneliness and individualization along with technology and because of an exam-oriented and teacher-centered education system. The role of the teacher as a facilitator in the Scouting organization is to jointly compile a program of activities that the organization will carry out within a certain period.

The teacher will acquire leadership qualities towards students when proposing activities, which will motivate students and keep them active within a student-centered understanding framework. Creating leadership opportunities for each student equally and bringing broader thinking skills about the spirit of leadership. Resulting in students expressing themselves better as individuals and developing different perspectives to recognize themselves and what is happening around them. The teacher's role is very important in terms of expressing the above opinion. activities that can be carried out outside the classroom for the acquisition of leadership qualities that will be useful for carrying out various social activities that will have an impact on the students themselves.

PMR extracurricular coaches in Indonesia as well as in the Province of East Java and the Tulungagung Regency specifically seek to foster leadership potential, social spirit, good coordination, and responsiveness of students. Carrying out regular blood donation activities within a certain period to foster a social spirit and a sense of empathy for students. Meanwhile, PMR activities that collaborate with students of the Nursing expertise program at SMKN seek to interact with the surrounding community, namely becoming a medical team in the activity.

From the results of all, teachers who provide opinions about the knowledge and understanding of leadership to obtain leadership qualities to students, namely leadership must be understood conceptually and actualized by both the teacher and the students themselves. These leadership qualities in students can be useful and will be superior. It would be useful to provide a conceptual framework and application-oriented activities on organizational leadership in schools. Also, various presentations and activities about the lives of leaders who have made history and can be role models for students can be carried out in organizational and school environments.

\section{Recommendation}

It is better if student organization activities are used as optimally as possible to develop the potential for the spirit of leadership to these students because it is something that is needed in facing the future of students. Organizational activities at the two SMKs have been well and optimal, but still, need to be improved. For SMK, it is better if it is necessary to hold activities related to the community, this is felt to be more effective in developing the leadership potential of students because they directly interact with the community so that they have experienced as a leader and how should the attitude of a leader be in good communication.

In the PMR organization, teachers have made good efforts to develop the potential for a human spirit and leadership traits for students. So that, it is hoped that it can optimize efforts to develop student leadership potential, PMR activities at SMK need to involve and interact with the community. This is considered more effective because students learn to lead and interact with the wider community.

\section{REFERENCES}

[1] Amiartuti. 2012. The Role of Leadership in Shaping Individual Behavior in Organizations at Umkm (Case Study of Leadership Management for Genteng UMKM in Trenggalek). Mahardhika Media Vol. 11 No 1: 127-143.

[2] Amiranti, Fitra. 2013. The Influence of Teacher Leadership in the Learning Process on Student Participation in the VII Class of Social Studies Economics at SMP Negeri 3 Patebon Kendal Academic Year 2012/2013. Economic Education Analysis Journal EEAJ 2 (2): 31-38.

[3] Apriyani, Muthmainnah. 2014. Efforts to Improve Student Council Leadership Attitudes Through Sociodramas at Kasihan Bantul Yogyakarta 1 Public High School. PSIKOPEDAGOGIA Journal Vol. 3, No.1 ISSN: 2301-6167.

[4] Arianto, Sarjiman. 2012. The Influence of Leadership and Work Motivation on Employee Performance in IPdn Jatinangor Sumedang, West Java. DIA, Journal of Public Administration Vol. 10, No. 2, pp. 75 - 82. 
[5] Adair, J. (2011). The John Adair Lexicon of leadership: The definitive guide to leadership skills and knowledge. London: Kogan Page Limited.

[6] Bloomberg, Linda Dale, and Marie Volpe. 2008. Completing Your Qualitative Dissertation: A Road Map From Beginning To End. SAGE Publications, Inc.

[7] Bennis, W. (2009). Become a leader. NY: Perseus book group.

[8] Chai, Ming Sing. 2015. Personality and Leadership Qualities among Student Leaders. American Journal of Applied Psychology 2015; 4 (3-1): 27-32.

[9] Çubukçu, Z., \& Gültekin, M. (2006). İlköğretimde ögrencilere kazandırılması gereken sosyal beceriler [Social skills that should be brought to students in primary education]. Bilig Bahar, (37).

[10] Cooper, DL, Healy, MA, \& Simpson, J. (1994). Student development through engagement: Specific changes over time. College Student Development Journal, 35 (2), 98-102.

[11] Drago-Severson, E. (2004). Helping teachers learn Principal leadership for adult growth and development. Corwin Press.

[12] Djafar, Hamsiah. 2017. Leadership Model in Character Development of Students at Labuang State High School, Polewali Mandar Regency. Idaarah Journal, VOL. I, NO. 2: 191-199.

[13] Ermita. 2015. Teacher Leadership in Implementation of Classroom Tasks. PEDAGOGY Scientific Journal of Educational Sciences Volume: XV No.2: 31-41.

[14] Fertman, CI, \&. Van Linden, JA (1999). Character education to develop youth leadership. The Education Digest, 65 (4), 11-16.

[15] Hakim, Abdul, and Hadipapo, Anwar. 2015. The Role of Leadership and Organizational Culture on Human Resources Performance in Wawotobi. Ekobis Vol. 16, No.1, January 2015: 21-11.

[16] Hancock, D., Dyk, PH, and Jones, K. 2012. Adolescent Involvement in Extracurricular Activities: Influences on Leadership Skills. Journal of Leadership Education, Volume 11, Issue 1 - Winter 2012: 84-101.

[17] Ingleton, Taneisha. 2013. College Student Leadership Development: Transformational Leadership as a Theoretical Foundation. International Journal of Academic Research in Business and Social Sciences Vol. 3, No. 7: 219-229.

[18] Jannesari, H., Iravani, MR, Masaeli, A., Dareshori, EF, and Ghorbani, A. 2013. A social work study on the relationship between transactional and laissez-fair leadership style and personality traits: A case study of the educational system. Management Science Letters 3 (2013) 813-820.

[19] Kiersch, Christa \& Peters, Janet. 2017. Leadership from the Inside Out: Student Leadership Development within Authentic Leadership and Servant Leadership Frameworks. Journal of Leadership Education DOI: 1012806 / V16 / I1 / T4: 148-168.

[20] Labor, Jonalou SJ. 2017. Filipino Student Council Heads' Leadership Frames: A Phenomenographic Inquiry. The Journal of Student Leadership. Volume 1 Issue 1.25-35.

[21] Lestari, Ria Yuni. 2016. The Role of Extracurricular
Activities in Developing the Citizenship Character of Students. Ucej, Vol. 1, No. 2, December 2016, p. 136-152 Untirta Civic Education Journal ISSN: 2541-6693.

[22] Muhammad, Azamul Fadhly Noor. 2017. Teacher Leadership Model in the Learning Process in the Classroom at the SD / MI Level. AL IBTIDA: Mi Journal of Teacher Education (2017) Vol 4 (1): 29-44.

[23] Muhsin. 2008. The Effect of Teacher Leadership and Communication on Learning Motivation. Journal of Economic Education Vol 3 No 2: 271-296.

[24] Mulhamah. 2017. Education and Basic Leadership Training for Ma Putra Al-Ishlahuddiny Students in West Lombok. Independent Society Journal, Vol. 1, No. 1, December 2017, p. 34-45 ISSN 2598-8158.

[25] Mulyana, Nanang. 2017. The Relationship between Teacher Leadership Style in Improving Learning Motivation of Physical Education in Elementary School Students. Journal of Physical Education and Sports Volume 9 Number 1. April 2017: 41-47.

[26] Mahfurianto, Rohman. 2017. The Influence of Pmr's Extracurricular Activities and Discipline on Social Skills of Junior High School 1 Geneng Students in 2014/2015 Academic Year. Citizenship Journal of Pancasila and Citizenship Education: 408-418.

[27] Foreman, EA, \& Retallick, MS (2012). Undergraduate involvement in extracurricular activities and leadership development in agricultural and life sciences student colleges. Journal of Agricultural Education, 53 (3), 111.

[28] Nasution, Nur Wahyudin. 2015. Educational Leadership in Schools. Tarbiyah Journal, Vol. 22, No. 1 (ISSN: 0854-2627): 66-86.

[29] Northouse, PG (2015). Leadership: Theory and practice. Wise publication.

[30] Osman, A., Manaf, AHA, \& Abdullah, MS 2014. An Analysis of Student Leadership Behavior: A Higher Education Institutional Perspective. International Journal Of Scientific \& Technology Research Volume 3, Issue 8, August 2014 Issn 2277-8616.

[31] Regulation of the Minister of Education and Culture of the Republic of Indonesia Number 62 of 2014 concerning Extracurricular Activities in Primary and Secondary Education.

[32] Posner, Barry Z. 2012. Effectively Measuring Student Leadership. Administrative Science. 2012, 2, 221-234; DOI: 10.3390 / admsci2040221.

[33] Ramirez. Ramona Isabel S. 2017. Student Leadership Role for Environmental Protection. Asia Pacific Journal of Multidisciplinary Research, Vol. 5, No. 2: 2014-211.

[34] Sari, Sindang, and Hendro, Omar. 2017. The Effect of Creativity, Communication, and Teacher Leadership on Student Achievement at SMP N in Ilir Timur 2 Palembang. JOURNAL Ecoment Global Volume 2 Number 1 February 2017 Edition: 74-87.

[35] Sari, Yuke Maduratna, and Sarmini. 2017. The Role of Basic Student Leadership Training Activities in Fostering Student Leadership Attitudes. Moral \& Citizenship Studies. Volume 05 Number 3 Volume 2 Year 2017, 516 - 530. 
[36] Sutton, EM, \& Terrell, MC (1997). Identify and develop leadership opportunities for African American men. New Directions for Student Services, 1997 (80), 55-64.

[37] Septiani, Irma, and Wiyono, Bambang Budi. 2012. Management of Extracurricular Activities in Improving School Quality. Educational Management VOLUME 23, NUMBER 5: 424-433.

[38] Soria, Krista M, et.al. 2013. Undergraduate Student Leadership and Social Change. Journal of College \& Character VOLUME 14, No. 3: 241-251.

[39] Suprapto. 2013. PAI EXTRACURRICULAR DEVELOPMENT: A Case Study at SMAN I Mataram, NTB. Educational Journal Volume 11, Number 2: 231-244.

[40] Suryadi and Tinov, MYT 2013. Leadership in Improving Student Achievement. Journal of Public Policy, Volume 4, Number 1: 31-36.

[41] Syakir, M., Hasmin, Sani, A. 2017. Analysis of extracurricular education activities for the formation of a disciplinary character of students at SMA Negeri 1 Sinjai Borong. Mirai Management Journal, Volume 2 Number 1: 108-125.

[42] Tüysüz, B. (2007). Öğrenci liderliği programının 6.sınıf öğrencilerinin liderlik rolleri ve davranışlarına etkisinin incelenmesi [An examination of the influence of student leadership programs on the role and leadership behavior of 6th students in the classroom]. (Yayımlanmamıs doktoratezi). Marmara Üniversitesi, İstanbul.
[43] Umam, Khairul. 2013. The Effect of Extracurricular Activities on Science Achievement and Student Social Behavior. Journal of Opportunities, Volume 1, Number 2 (ISSN: 2302-5158): 93-96.

[44] Education System Law National (SISDIKNAS) 2003 on the National Education System.

[45] Yudiaatmaja, Fridayana. 2013. Leadership: Concept, Theory, and Character. Media Communications FIS Vol 12, No 2: 29-38.

[46] Irvin, LE, \& White, D. (2004). Keys to Effective Leadership. Principal Leadership, 4 (6), 20-24.

[47] McGregor, J. (2007). Recognizing student leadership: schools and networks as sites of opportunity. Improving Schools, 10 (1), 86-101.

[48] Whitehead, G. (2009). Adolescent Leadership Development Building a Case for an Authenticity Framework. Educational Management Administration \& Leadership, 37 (6), 847-872

[49] Zeldin, S., \& Camino, L. (1999). Youth leadership: Linking research and program theory to exemplary practice. research and practice: Completing the circle. New Designs for Youth Development, 15 (1), 10-15.

[50] Hanafi Parlar, M. emin. T \& Ramazan. 2019. Leadership Development in Students: Teachers' Opinions Regarding Activities that can be Performed at Schools: Universal Journal of Educational Research 5 (2): 217-227, 2017. 